\title{
Наш опыт резекции гигантской акинетической аневризмы левого желудочка (с угрозой разрыва стенки) с пластикой левого желудочка и аортокоронарным шунтированием (случай из практики)
}

\author{
Джуманиязов А. А. \\ Хорезмский филиал Республиканского специализированного центра кардиологии (Узбекистан)
}

\begin{abstract}
Методика пластики левого желудочка (ЛЖ) двухъярусным швом с одномоментным устранением перегородочной части купола головки аневризмы путем ее гофрирования нижнеярусным швом является эффективным методом пластики ЛЖ после резекции средних и больших аневризм левого желудочка (АЛЖ).

Цель работы - анализ опыта внедрения в практику Центра методики пластики ЛЖ двухъярусным швом с одномоментным устранением перегородочной части купола головки аневризмы путем ее гофрирования нижнеярусным швом, разработанной в НИССХ имени Н. М. Амосова.

Материалы и методы. Пациент Ю. Ж., 57 лет, дважды перенес ОИМ - в 2012 и 2017 гг. Выполнена коронаровентрикулография, на которой - множественные поражения коронарных артерий сердца; КДО ЛЖ - 430 мл, ФВ ЛЖ - 28\%. На ЭхоКГ - аневризма ЛЖ, истончение стенки АЛЖ, тромбоз ЛЖ, КДО ЛЖ - 367 мл, ФВ ЛЖ - 37\%. Выполнена операция: аортокоронарное шунтирование, резекция аневризмы левого желудочка (аневризмэктомия), тромбэктомия из ЛЖ, эндовентрикулопластика ЛЖ с пликацией межжелудочковой перегородки в условиях ИК и КП.

Результаты и обсуждение. После операции у пациента одышки нет, увеличилась толерантность к физической нагрузке, КДО ЛЖ уменьшился с 430 до 212 мл, ФВ ЛЖ увеличилась с 28 до 48\%. Через 2 месяца после операции больному проведена нагрузочная проба - тредмил-тест, на котором толерантность к физической нагрузке средняя, МЕТ 5.4. В ходе проведения теста признаков ишемии миокарда и нарушения ритма сердца не отмечено. Методика, разработанная в НИССХ имени Н. М. Амосова, уже на госпитальном этапе после операции позволяет получить улучшенные показатели сократительной функции ЛЖ. Данные контрольной эхокардиографии (ЭхоКГ) показали эффективность и надежность методики в восстановлении адекватной геометрии полости ЛЖ при многих вариантах АЛЖ.

Выводы. Разработанная методика уже на госпитальном этапе после операции показывает положительную динамику в состоянии пациента, позволяет получить улучшенные показатели сократительной функции левого желудочка, о чем свидетельствует достоверное увеличение ФИ ЛЖ и уменьшение объемов ЛЖ.
\end{abstract}

Ключевые слова: ИБС, аневризма ЛЖ, аневризмэктомия, пластика ЛЖ.

АЛЖ образуются после перенесенного трансмурального инфаркта миокарда, в результате окклюзии одной из крупных коронарных артерий (КА). Травмы и ранения сердца с повреждением КА, как причина развития АЛЖ, составляют менее $1 \%$ случаев. По своей локализации АЛЖ характеризуют как передне-перегородочно-верхушечные и значительно реже - заднебазальные АЛЖ [11, 14].

Морфологическое понятие аневризмы сердца предполагает участок истонченной, несокращающейся рубцовой ткани, хорошо ограниченной от сохраненного миокарда и выпячивающейся над ним. Клинически АЛЖ характеризуется как участок рубцового изменения стенки ЛЖ, который визуально проявляется отсутствием движения (акинезия) во время сердечного цикла или парадоксальным движением (дискинезия) $[1,11,15]$. В зависимости от величины площади мешка аневризмы (по отношению к объему ЛЖ в диастолу) они делятся на аневризмы малые (10-15\%), средние (16-20\%) и большие (21-40\%).

В последние годы особенно интенсивно развивается направление допплеровской оценки диастолической функции ЛЖ с использованием скорости движения миокарда - тканевая допплеровская визуализация [4-6].

По эхокардиографическим признакам аневризмы ЛЖ разделяются на три основных типа (модификация классификации W. Stoney, 1994):

I - аневризмы с нормокинезом сокращающейся части ЛЖ, фракция выброса (ФВ) 50\%;

II - аневризмы с гипокинезией сегментов сокращающейся части ЛЖ (по Coltharp, 1994: нормокинезия передней стенки и гипокинезия задней стенки ЛЖ), ФВ более $30 \%$. 
III - аневризмы с выраженной гипокинезией стенок ЛЖ (по Coltharp, 1994: нормокинезия передней стенки и акинезия задней стенки), ФВ менее $30 \%$.

Показателями неблагоприятного прогноза у пациентов с аневризмой ЛЖ, по данным ЭхоКГ, являются:

- выраженная дилатация ЛЖ: конечный диастолический размер > 7,6 см; конечный систолический размер $>4,5-5,0$ см; индекс сферичности $>0,76$;

- тяжелая систолическая дисфункция: ФВ ЛЖ < 35\%;

- признаки высокого давления наполнения ЛЖ: псевдонормальный и рестриктивный трансмитральный кровоток;

- выраженная митральная регургитация;

- развитие фибрилляции предсердий и выраженной легочной гипертензии (>50 мм рт. ст.) даже при сохраненной ФВ ЛЖ $>35 \%$.

Распространенность АЛЖ среди пациентов, перенесших инфаркт миокарда, составляет от $10 \%$ до $35 \%$. Среди обследованных пациентов, по данным CASS, 7,6\% имеют ангиографически доказанную АЛЖ [12]. Общая распространенность АЛЖ должна снизиться при своевременном применении современных методов лечения острого коронарного синдрома, таких как перкутанная коронарная ангиопластика и стентирование KА, а также тромболитической терапии $[9,10]$.

Наряду с наличием приступов стенокардии (СK), основными клиническими проявлениями у пациентов с АЛЖ является прогрессирующая сердечная

недостаточность, системные тромбоэмболии и нарушения ритма сердца. Снижение систолической функции ЛЖ наступает вследствие выключения из процесса сокращения участка миокарда, превышающего 20-22\% площади ЛЖ в период диастолы [14]. В этих условиях участки неповрежденного миокарда гипертрофируются и растягиваются, чтобы компенсировать сниженную функцию миокарда. Когда это растяжение адекватно не компенсирует сниженную сократимость, нарушается нормальное соотношение «давление-объем». Это ведет к росту конечно-диастолического давления (КДД ЛЖ), развитию митральной недостаточности, повышению давления в легочной артерии (ЛА), и заболевание переходит в стадию дилатационной кардиомиопатии.

Несмотря на полувековой опыт хирургического лечения этой патологии, продолжают дискутироваться вопросы выбора пластики ЛЖ после аневризмэктомии $[2,3,7,14,15]$.

Хирургические методы предполагают оперативное устранение аневризмы с последующим восстановлением целостности ЛЖ, одновременно с шунтированием коронарных артерий (ШКА). В настоящее время используется несколько методик пластики ЛЖ после аневризмэктомии, направленных на восстановление его объема и геометрии. Все они являются модификациями методов, разработанных в 60-е годы 20 века
A. Jatene et V. Dor, которые нашли, что линейная пластика АЛЖ мало эффективна, и предложили использовать заплаты из дакрона для уменьшения объема и восстановления геометрии ЛЖ. Эти методы позволили улучшить непосредственные и отдаленные результаты, однако они недостаточно полно решают проблему низкой производительности сердца. Объяснить это можно тем, что искусственно созданная зона акинезии самой заплатой продолжает оставаться причиной значимого расхождения (диастаза) краев винтообразно сокращающегося мышечного каркаса, особенно среднего слоя, что отрицательно сказывается на нагнетательной функции желудочковой камеры. Поэтому плохая сердечная функция остается основной причиной смерти, неудовлетворительных ранних и отдаленных результатов хирургического лечения АЛЖ. Статистическое снижение этих показателей не может стать очевидным, пока не улучшатся хирургические методы лечения АЛЖ, над совершенствованием которых необходимо продолжать интенсивно работать.

Цель работы - анализ опыта внедрения в практику центра методики пластики ЛЖ двухъярусным швом с одномоментным устранением перегородочной части купола головки аневризмы путем ее гофрирования нижнеярусным швом, разработанной в НИССХ имени Н. М. Амосова.

Больной Ю. Ж., 57 лет. В 2010 году у больного впервые выявлено повышение артериального давления (макс. 190/120 мм рт. ст.), лечился амбулаторно. В июне 2012 г. перенес острый инфаркт миокарда с зубцом $\mathrm{Q}$ передней стенки ЛЖ, лечился нерегулярно. В июле 2017 г. в связи с сильными болями в груди доставлен в реанимационное отделение по месту жительства, где обследован. Выявлен повторный общирный ОИМ передне-боковой стенки ЛЖ, и проведено стационарное лечение. Из-за неэффективности консервативной терапии больной обратился в ХФ РИКМ, где 25.08.2017 выполнена коронаровентрикулография (рис. 1-4).

Больному выполнена ЭхоКГ-исследование, на котором выявлена АЛЖ с истончением стенки аневризмы с угрозой разрыва; КДО ЛЖ - 367 мл, общая сократимость ЛЖ - 37\%, в области верхушки - 19-22\% (рис. 5).

В связи с выраженной хронической сердечной недостаточностью ІІБ ст., ФК IV по NYHA и сопутствующим сахарным диабетом II типа в стадии декомпенсации больному амбулаторно и в стационарных условиях проведена консервативная терапия препаратами ризопролол, верошпирон, энап, роксера, тромбоасс, глюкатон, нитроминт.

24.10.2017 г. Больной Ю. Ж., 57 лет, оперирован по жизненным показаниям (с подготовкой внутриаортального баллонного контрпульсатора) с диагнозом: ИБС. ПИКС (2012, 2017 гг.). Стенокардия напряжения ФК III. АГ I, риск IV. Гигантская акинетическая аневризма левого желудочка (с угрозой разрыва стенки аневризмы 


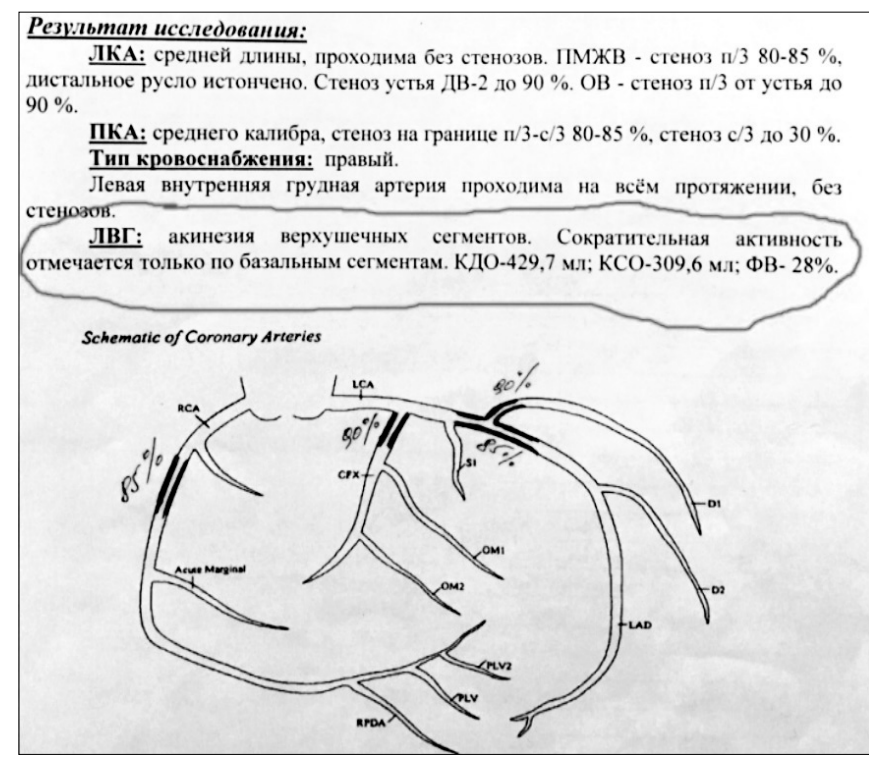

Рис. 1. Результаты коронарографии

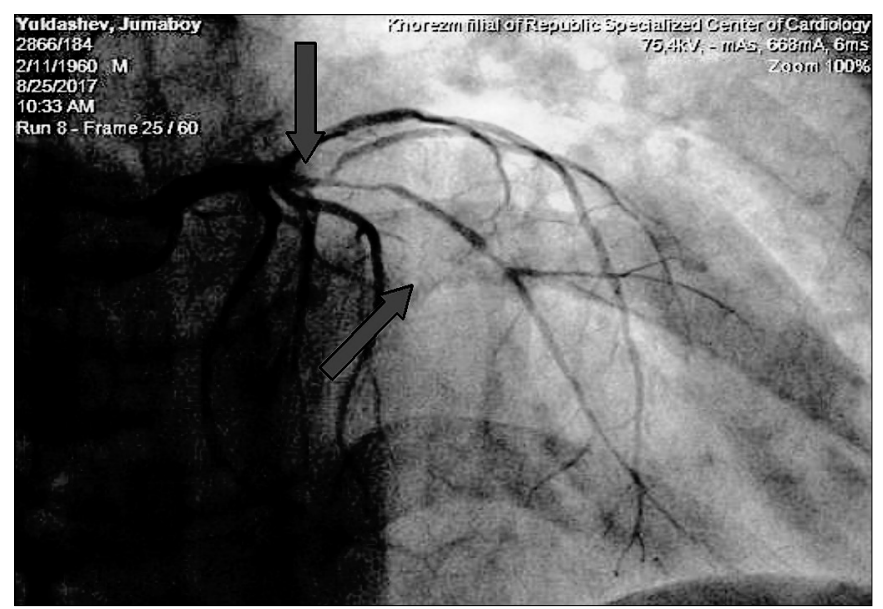

Рис. 3. ЛКА: средней длины, проходима, без стенозов. ПМЖВ - стеноз n/3 80-85\%, дистальное русло истончено. Стеноз устья ДВ-2 до 90\%. ОВ стеноз $\mathrm{n} / 3$ от устья до $90 \%$

левого желудочка). Осл.: ХСН ІІБ ст., ФК ІІІ по NYHА. Соп: Сахарный диабет II тип, тяжелое течение.

Выполнена операция: аортокоронарное шунтирование (ОВ ЛКА, ЗМЖВ ПКА), резекция аневризмы левого желудочка, тромбэктомия из ЛЖ, эндовентрикулопластика ЛЖ с пликацией межжелудочковой перегородки в усл. ИК (126 мин.) и КП (81 мин.).

Интраоперационно: сердце увеличено в размерах, сократимость ЛЖ резко снижена, передняя стенка ЛЖ не сокращается, там же визуализируется гигантская аневризма передней стенки ЛЖ, с охватом верхушки и боковой стенки ЛЖ, ПМЖВ ЛКА расположена в зоне аневризмы ЛЖ, тонкая, диаметр ее меньше 1 мм

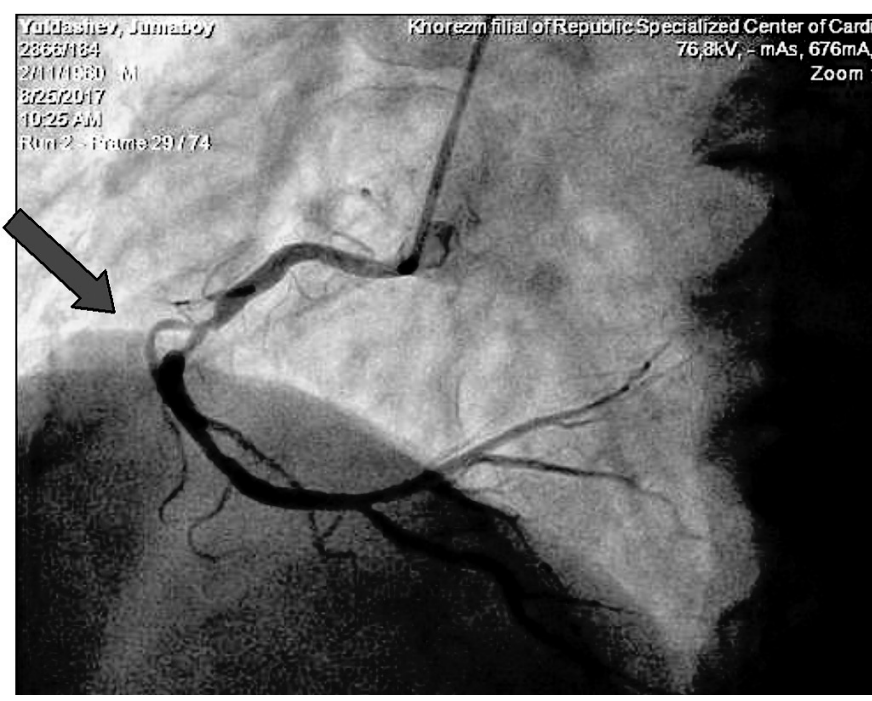

Рис. 2. ПКА: среднего калибра, стеноз на гранище $n / 3-c / 3$ $80-85 \%$, стеноз $\mathrm{c} / 3$ до $30 \%$

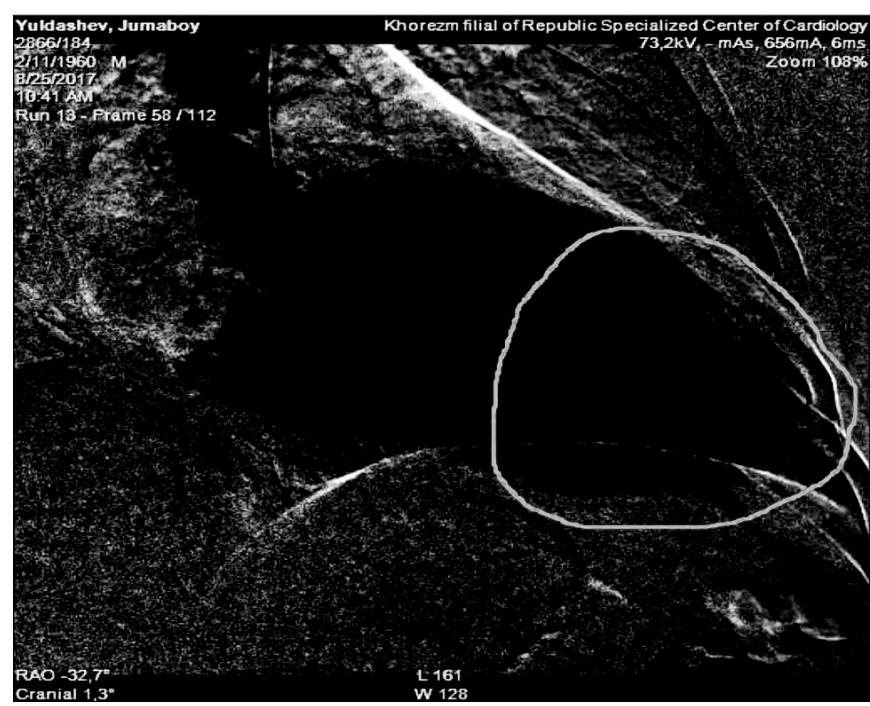

Pис. 4. ЛВГ: акинезия верхушечных сегментов.

Сократительная активность отмечается только по базальным сегментам. КДО - 429,7 мл; КСО - 309,6 мл; $\Phi B-28 \%$

- шунтирование ее нецелесообразно (рис. 6, 7). Разрез в области аневризмы передней стенки ЛЖ длиной 12 см: аневризма образована за счет передней стенки ЛЖ (4 см), МЖП (5 см) и верхушки ЛЖ (3 см); удалены рыхлые, «свежие» и пристеночные тромбы в количестве 500 г, полость ЛЖ многократно промыта физраствором; стенка ЛЖ рубцово изменена, резко истончена («как толщина бумаги»), произведена резекция аневризмы ЛЖ, тромбэктомия из ЛЖ, эндовентрикулопластика ЛЖ с пликацией межжелудочковой перегородки (рис. 8-10). 


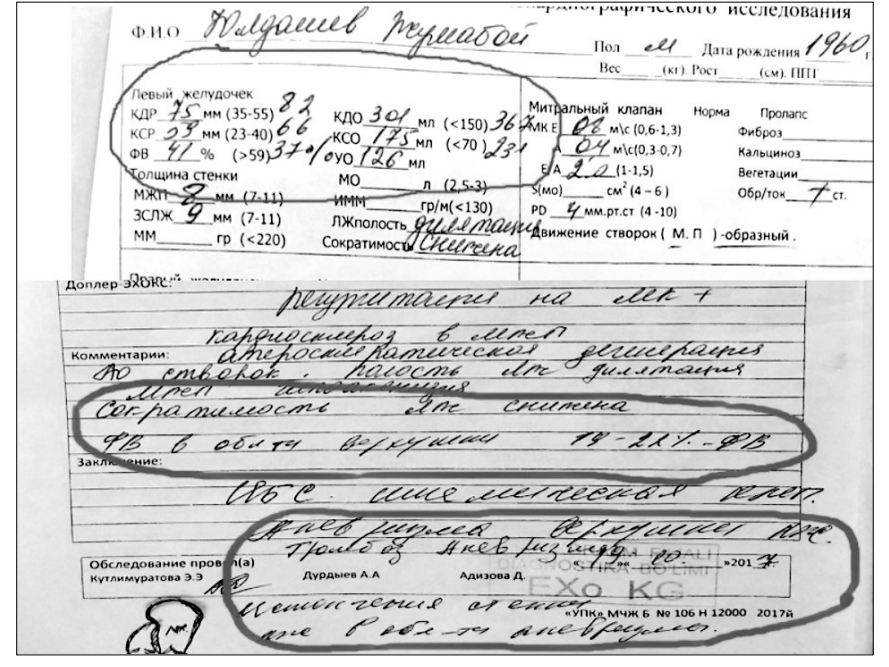

Рис. 5. Данные эхокардиографического исследования

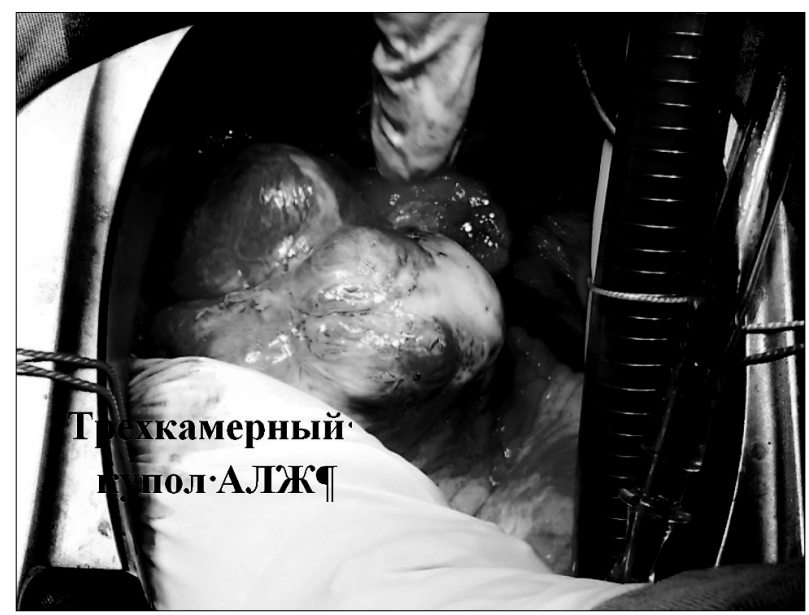

Рис. 7. Трехкамерный купол аневризмы левого желудочка

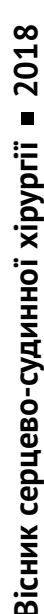

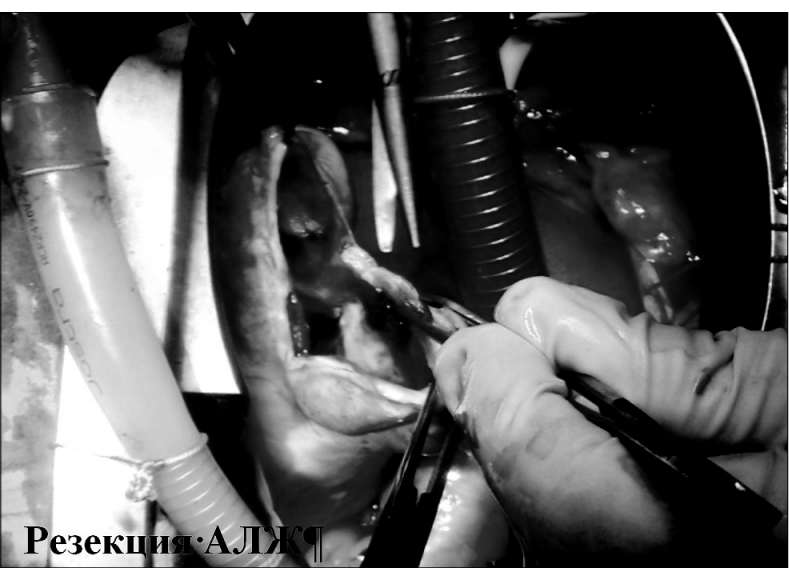

Рис. 9. Резекция аневризмы левого желудочка

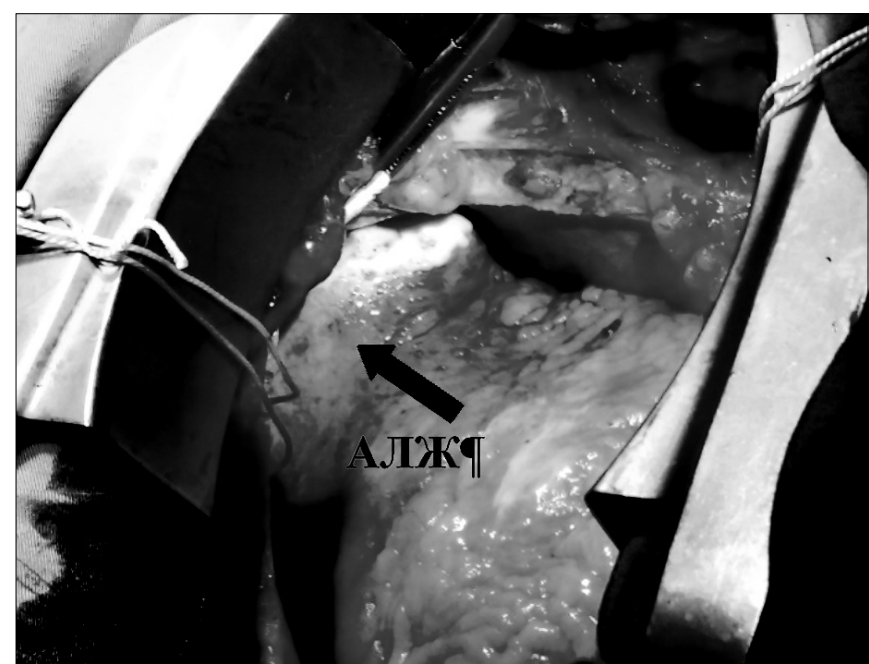

Рис. 6. Аневризма левого желудочка

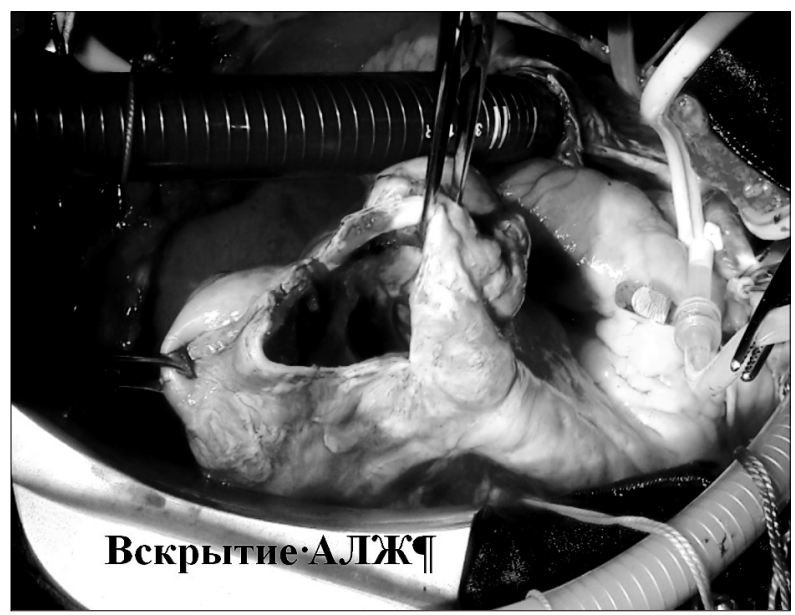

Рис. 8. Вскрытие аневризмы левого желудочка

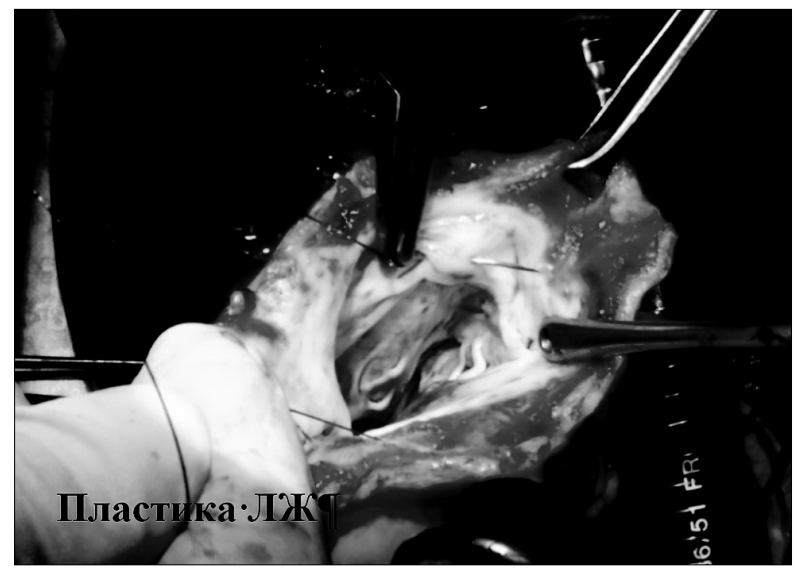

Рис. 10. Пластика левого желудочка 


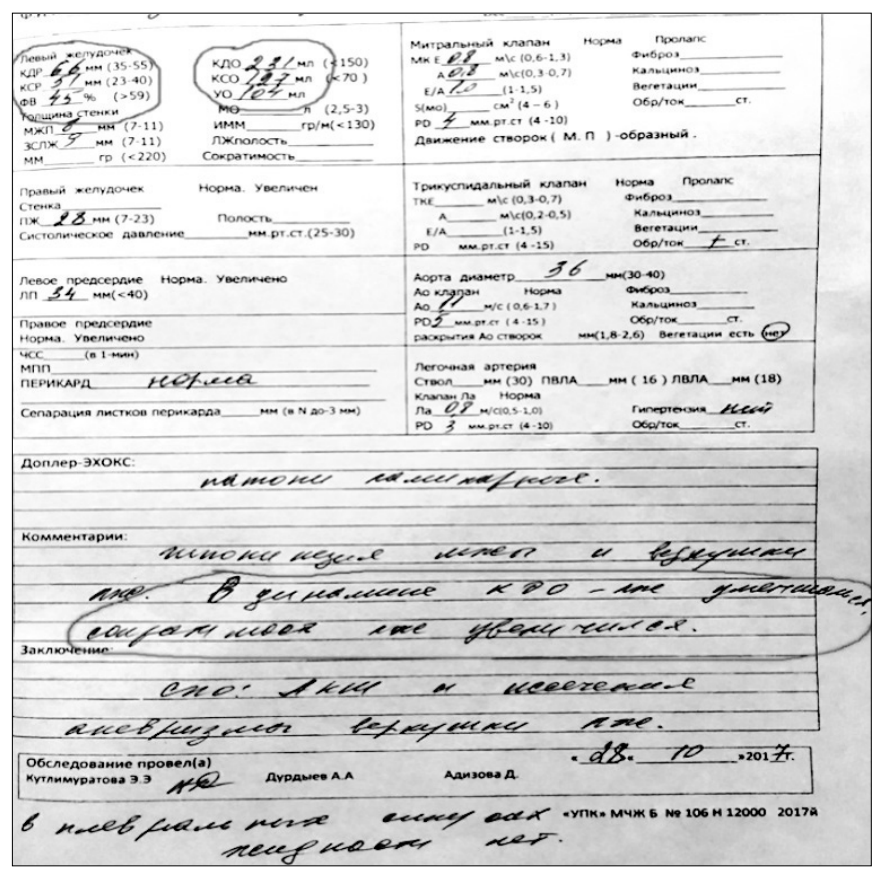

Рис. 11. ЭхоКГ на 4-е сутки после операции

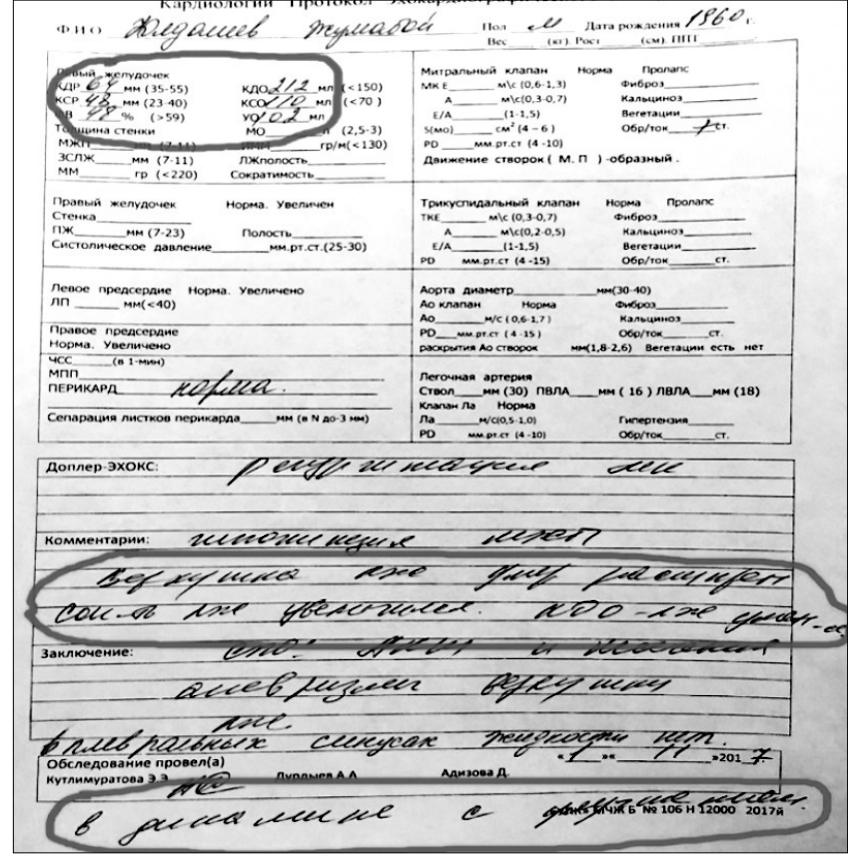

Рис. 12. ЭхоКГ на 8-е сутки после операщии
Резекция аневризмы и способ пластики дефекта ЛЖ. Разрез стенки аневризмы длиной 12 см выполнен параллельно межжелудочковой борозде на расстоянии 2,5-3 см от передней межжелудочковой веточки ЛКА, не доходя 1,5-2 см до крупной (первой) диагональной ветви ЛКА. Дистально разрез продолжен на верхушку ЛЖ, с переходом на ее заднюю поверхность, до границы основания аневризмы. Зажимами Аллиса захвачены края утолщенного эндокарда, удалены тромбы. Латеральная часть стенки аневризмы резецирована с ориентацией на границу фиброзно измененного эндокарда. Оставлена полоса фиброзного эндокарда шириной 1,5 см для наложения обвивного шва нижнего яруса; это снижает риск прорезывания швов, что гарантирует надежную консолидацию сопоставленных краев эндокарда. Нижнеярусный обвивной шов наложен так, чтобы одновременно гофрировалась МЖП, он начат нитью пролен № 2 у основания передней и задней медиальных папиллярных мышц митрального клапана. В нижнем от верхушки ЛЖ крае основания аневризмы наложен П-образный шов, затянут и связан. Затем одной ниткой сделан 1 стежок по основанию аневризмы, до наружного разреза стенки аневризмы, затем выкол последнего шва наружу, между краем разреза и ПМЖВ. Второй иглой наложен шов на широкое основание купола аневризмы. Последний стежок на перегородке закончен на 5 мм ниже края эндокарда. Таких швов сделано 5, чтобы сблизить 2/3 основания головки аневризмы. Подобным швом и таким маневром наложен второй нижнеярусный шов, начиная с верхушки сердца. При подтягивании клюшкообразным пинцетом за среднюю петлю нижнего шва, натяжением нитки плотно сведены края основания головки аневризмы. Второй ниткой, выколотой наружу, обвивным швом сшиты края разреза до границы первой нитки, и они связаны. Прекращен отсос крови из ЛЖ, последняя заполнена кровью, и стянуты края основания аневризмы другим, нижнеярусным швом. После этого сшиты края разреза. При сшивании краев раны использованы укрепляющие швы, при которых глубоким вколом иглы в бессосудистой зоне нитки проведены через все слои, почти у основания аневризмы. Затем проведена профилактика воздушной эмболии, и после восстановления адекватной гемодинамики ИК остановлено.

Хотя ранее проведенные исследования свидетельствовали о невысокой выживаемости пациентов с дискинетической аневризмой ЛЖ, получавших медикаментозную терапию (12\% до 5 лет), последние исследования показали пятилетнюю выживаемость данной категории больных от 47\% до 70\% [12, 8-13]. Среди причин смертиуказаны: аритмия - 44\%, СН - 33\%, повторный ИМ - 11\%, внесердечные причины - 22\% [13]. Литературных данных о выживаемости пациентов с акинетической аневризмой ЛЖ недостаточно. Дооперационными факторами риска отдаленной летальности являются возраст, фракция выброса $<35 \%$, КДД левого желудочка >20 мм рт. ст. и митральная недостаточность.

Наиболее частым осложнением в госпитальном периоде является синдром малого сердечного выброса, а 
также желудочковые аритмии и легочная недостаточность.

В отдаленном послеоперационном периоде улучшается функция левого желудочка: возрастает фракция выброса, уменьшается КДО и КСО левого желудочка, диастолическое наполнение и комплаейнс, увеличивается толерантность к физической нагрузке. Средний класс стенокардии снижается с 3,5 до 1,2, а класс сердечной недостаточности по классификации NYHA - с 3,0 до 1,7. Результаты непосредственно зависят от метода ремоделирования левого желудочка, демонстрируя явное преимущество линейной пластики.

В нашем случае у пациента после операции полностью исчезла одышка, КДО ЛЖ уменьшился с 430 до 212 мл, ФВ ЛЖ увеличилась с 28 до 48\% (рис. 11, 12). Через 2 месяца (21.12.2017 г.) после операции больному проведена нагрузочная проба - тредмил-тест, на котором толерантность к физической нагрузке средняя, МЕТ 5.4. В ходе проведения теста признаков ишемии миокарда и нарушения ритма сердца не отмечено, проба была остановлена из-за утомления больного с максимальной ЧСС 121 уд. в мин.

\section{Выводы}

1. Методика пластикилевого желудочкадвухъярусным швом с одномоментным устранением перегородочной части купола головки аневризмы оригинальным способом ее гофрирования нижнеярусным швом является эффективным методом хирургического лечения средних и больших АЛЖ.

2. Разработанная методика уже на госпитальном этапе после операции позволяет получить улучшенные показатели сократительной функции левого желудочка, о чем свидетельствует достоверное увеличение ФИ ЛЖ и уменьшение объемов ЛЖ.

3. Данные контрольной эхокардиографии показали эффективность и надежность методики в восстановлении адекватной геометрии полости ЛЖ при многих вариантах АЛЖ.

\section{Литература}

1. Варианты подготовки больных ИБС с низкой фракцией выброса левого желудочка перед коронарным шунтированием / Григорьев Е. В., Гейзе А. В., Сизова И. Н. и др. // Кардиология и сердечно-сосудистая хирургия. -2012 . - Т. 5, № 1. - С. 88-93.

2. Непосредственные результаты аневризмэктомии с эндовенрикулопластикой в лечении больных с постинфарктной аневризмой левого желудочка / Акчурин Р. С., Ширяев А. А., Галяутдинов Д. М. и др. // Бюллетень НЦССХ им. А. Н. Бакулева РАМН, сердечно-сосудистые заболевания, 12 Всероссийский съезд сердечно-сосудистых хирургов. - Москва. - 2831 октября 2007. - С. 56.
3. Непосредственные результаты хирургического лечения постинфарктных аневризм левого желудочка / Взязников В. А., Пенегин В. Р., Вознесенская Е. Н. и др. // Бюллетень НЦССХ им. А. Н. Бакулева РАМН, сердечно-сосудистые заболевания, 12 Всероссийский съезд сердечно-сосудистых хирургов. - Москва. - 2831 октября 2007. - С. 70.

4. Изменения миокардиальной фукнции левого желудочка у больных с постинфарктным кардиосклерозом по данным тканевой допплеровской визуализации после аортокоронарного шунтирования, комбинированного с аневризмэктомией левого желудочка / Долженко М. Н., Руденко А. В., Поташев С. В. и соавт. // Серце і судини. - 2008. - № 2. - С. 34-41.

5. Диагностическая ценность современных методов визуализации сердца у пациентов с постинфарктной аневризмой левого желудочка / Долженко М. Н., Руденко А. В., Поташев С. В. и др. // Серце і судини. 2009. - № 1. - С. 74-80.

6. Руденко С. А. Аневризма левого желудочка: современные принципы хирургического лечения // Симпозіум. - 2008. - № 5 (51). - С. 65-68.

7. Аналіз безпосередніх результатів лікування аневризм лівого шлуночка серця з різко зниженою фракцією викиду / Руденко С. А. та ін. // Серцево-судинна хірургія: Щорічн. наук. праць Асоціації серцево-судинних хірургів України. - К., 2013. - Вип. 21. - С. 445-447.

8. Ургентное аортокоронарное шунтирование на работающем сердце после тромболитической терапии на фоне острого коронарного синдрома / Урсуленко В. И., Гогаева Е. К и др. // Кардиохирургия и интервенционная кардиология. - 2015. - № 2. - С. 35-38.

9. Ventricular aneurysm resection: trends in surgical risk / Cosgrove D. M., Lytle B. W., Taylor P. C. et al. // Circulation. - 2014. - Vol. 79 (suppl I). - P. 97.

10. Ventricular aneurysmectomy: a 25-year experience / Coltharp W. H., Hoff S. J., Stoney W. S. et al. // Ann Surg. - 1994. - Vol. 219. - P .707.

11. Surgical ventricular reconstruction with radiofrequency ablation-induced markings / Babokin V., Shipulin V., Batalov R., Popov S. // J. Thorac Cardiovascular Surgery. 2013. - Vol. 146 (5). - P. 1133-8.

12. Faxon D. P., Ryan T. J., David K. B. Prognostic significance of angiographically documented left ventricular aneurysm from the Coronary Artery Surgery Study (CASS) // Am J Cardiol. - 2013. - Vol. 50. - P.157.

13. Natural history of saccular aneurysm of the left ventricle / Grondin P., Kretz J. G., Bical O. et al. // J Thorac Cardiovasc Surg. - 2015. - Vol. 77. - P. 57.

14. Jatete A. O. Left ventricular aneurysmectomy resection on reconstruction // J. Thorac Cardiovasc Surg. -2015. Vol. 59. - P. 321.

15. Surgical therapy for left ventricular aneurysms; A ten year experience // Magovern G. J., Sakert T., Simpson K. et al. // Circulation. - 2016. - Vol. 79 (suhhl 1). - P. 100104. 


\section{Our experience of resection of a giant akinetic aneurysm of the left ventricle (with the threat of a rupture of the wall) with left ventricular plasty and aorto-coronary bypass grafting (case from practice) \\ Djumaniyazov A. A. \\ Khorezm branch of the Republican Specialized Cardiology Center (Uzbekistan)}

The technique of left ventricular plasty by a two-tiered seam, with simultaneous elimination of the septal part of the dome of the aneurysm head by corrugating it with a lower-tiered suture, is an effective method of plasty of the left ventricle after a resection of medium and large left ventricular aneurysms.

Our goal is introduction of the practice of the center of the technique of left ventricular plastic surgery by a double-tiered seam, with simultaneous elimination of the septal part of the dome of the aneurysm head by corrugating it with a lowertiered seam developed at the National Institute of Cardiovascular Surgery named after N. M. Amosov.

Material and methods. Patient Yu. J., 57 years old, twice suffered a myocardial infarction in 2012 and 2017. The patient underwent coronaroventriculography, which revealed multiple lesions of the coronary arteries of the heart. The operation was performed: aortocoronary bypass, left ventricular aneurysm resection, LV thrombectomy, LV endventriculoplasty with plication of the interventricular septum in conditions of artificial blood circulation and cardioplegia.

Results and discussion. After the operation, the patient does not have shortness of breath, increased tolerance to physical exertion, end diastolic LV volume decreased from 430 to $212 \mathrm{ml}$, LVEF increased from 28 to $48 \%$. Two months after the operation, the patient underwent a stress test-a treadmill test, in which the exercise tolerance was average, MET 5.4, during the test for signs of myocardial ischemia and cardiac arrhythmias were not observed. The developed technique at the National Institute of Cardiovascular Surgery named after NM Amosov, already at the hospital stage after surgery, allows to obtain improved LV contractility. The data of control echocardiography showed the effectiveness and reliability of the technique in restoring adequate LV cavity geometry, in many variants of left ventricle aneurysm to bring it closer to the natural form.

Conclusions. The developed method, already at the hospital stage after the operation, shows a positive dynamics in the patient's condition, allows to obtain improved parameters of the contractile function of the left ventricle, as evidenced by a significant increase in LVEF and a decrease in LV volumes.

Key words: IHD, aneurysm of the left ventricle, aneurysmectomy, $L V$ plastic.

\section{Наш досвід резекції гігантської акінетичної аневризми лівого шлуночка (із загрозою розриву стінки) із пластикою лівого шлуночка і аортокоронарним шунтуванням (випадок із практики)}

Джуманіязов А. А.

Хорезмський філія Республіканського спеціалізованого центру кардіології (Узбекистан)

Методика пластики лівого шлуночка (ЛШ) двоярусним швом, з одномоментним усуненням перегородкової частини купола головки аневризми шляхом ії гофрування нижньоярусним швом, $є$ ефективним методом пластики ЛШ після резекції середніх і великих аневризм лівого шлуночка (АЛШ).

Мета роботи - аналіз досвіду впровадження у практику Центру методики пластики ЛШ двоярусним швом з одномоментним усуненням перегородкової частини купола головки аневризми шляхом ії гофрування нижньоярусним швом розробленої в НІССХ імені М. М. Амосова.

Матеріали та методи. Пацієнт Ю.Ж., 57 років, двічі переніс ГІМ - у 2012 і 2017 гг. Виконана коронаровентрикулографія, на якій - множинні ураження коронарних артерій серця; КДО ЛШ - 430 мл, ФВ ЛШ- 28\%. На ЕхоКГ - аневризма ЛШ, витончення стінки АЛШ, тромбоз ЛШ, КДО ЛШ- 367 мл, ФВ ЛШ - 37\%. Виконана операція: аортокоронарне шунтування, резекція аневризми лівого шлуночка (аневризмектомія), тромбектомія 3 ЛШ, ендовентрикулопластика ЛШ з плікацією міжшлуночкової перегородки в умовах ІК і КП.

Результати та обговорення. Після операції в пацієнта задишки немає, збільшилася толерантність до фізичного навантаження, КДО ЛШ зменшився з 430 до 212 мл, ФВ ЛШ збільшилася з 28 до 48\%. Через 2 місяці після операції хворому проведена навантажувальна проба - тредміл-тест, на якому толерантність до фізичного навантаження середня, МЕТ 5.4, у ході проведення тесту ознак ішемії міокарда та порушення ритму серця не відзначено. Методика, розроблена в Національному інституті серцево-судинної хірургії імені М. М. Амосова, уже на госпітальному етапі після операції дозволяє отримати поліпшені показники скорочувальної функції ЛШ. Дані контрольної ехокардіографії (ЕхоКГ) показали ефективність і надійність методики у відновленні адекватної геометрії порожнини ЛШ при багатьох варіантах АЛШ.

Висновки. Розроблена методика вже на госпітальному етапі після операції показує позитивну динаміку в стані пацієнта, дозволяє отримати поліпшені показники скоротливої функції лівого шлуночка, про що свідчить достовірне збільшення ФМ ЛШ і зменшення обсягів ЛШ.

Ключові слова: ішемічна хвороба серия, аневризма ЛШ, аневризмектомія, пластика ЛШ. 